\title{
Yuen Yuen Ang, China's Gilded Age: The Paradox of Economic Boom and Vast Corruption
}

(Cambridge Et al.: Cambridge University Press, 2020), XV + 257p., \$39.99 Hardback, \$32.00 eBook

\section{Carolin Kautz ${ }^{1}$ (D)}

Accepted: 18 December 2020/Published online: 9 February 2021

(C) The Author(s) 2021

Why does rampant corruption in China exist side by side with rapid economic growth? This apparent paradox represents the research question of Yuen Yuen Ang's book on what she calls China's gilded age. For answering this question, Ang proposes that not every form of corruption hurts economic growth in the same way and creates what she calls the "unbundled corruption index (UCI)" (p. 27). Distinguishing petty theft (stealing and extortion among low-level officials), grand theft (embezzlement and misappropriation of large sums by higher-ranking officials), speed money (small bribes to circumvent red tape) and access money ("high-stakes rewards" (p. 10) from businesses for officials to obtain exclusive access and privileges), she argues that only the first three are directly harmful for economic growth. Contrary to this, Ang holds that access money can further economic growth and development by fostering investment and business activity, thereby acting as the "steroids of capitalism" (p. 12). She proposes that, similar to the US for example, corruption in China is dominated by access money rather than the other more damaging forms of corruption. According to her, these other forms were in China successfully limited with the help of administrative and regulatory reforms since the mid-1990s.

In the second half of her book, Ang analyses why access money is the most important pattern of corruption in China and why low wages for grassroots officials do not lead to these officials engaging in what she calls "speed money", i.e. petty extortionary bribery. Analyzing local government budgetary data, Ang argues that China's political system is dominated by a profit-sharing model where government officials have a personal interest in fostering economic growth in their localities. This incentive is due to the fact that they receive what Ang calls "fringe compensations" ( $p$. 97), e.g. bonuses and overtime pay, entertainment or access to cars. These are naturally higher in localities that are wealthier. In addition to this fringe compensation scheme,

Carolin Kautz

carolin.kautz@phil.uni-goettingen.de

1 Department of East Asian Studies, Georg-August-University, Goettingen, Germany 
Ang holds that even for notorious corruption cases of high-ranking cadres it cannot be argued that these are solely harmful for economic development. Based on two cases studies of the cases of Bo Xilai and Ji Jianye she concludes that these cadres are not only corrupt but often also competent, fostering large-scale economic projects in conjunction with access money and thus inducing economic development.

Lastly, Ang discusses the effects of Xi's current anticorruption campaign on economic growth and finds that performance of officials is not related to the probability of being purged during the campaign. Rather, she identifies patronage as the decisive factor. In terms of the impact on growth, she holds that the combination of strict anticorruption measures and tightened political control also in society and the economy at large can lead to a misalignment of incentives for officials who might struggle to combine strict political discipline and entrepreneurial risk taking in their localities.

Methodologically, Ang's study is based on an innovative and very rich data set. This includes the original "unbundled corruption index" that she proposes as an alternative to traditional corruption indices and that consists of the four forms of corruption named above. This index is based on expert surveys on forms of corruption. Furthermore, her study relies on numerous interviews with Chinese officials as well as local government budgetary data and procuratorate data on corruption cases. She then applies a mixedmethods approach in a very fruitful and convincing manner to this impressively rich and deep dataset.

In addition to her thorough empirical work, in theoretical terms Ang embarks on nothing less than a revision of our understanding of corruption. Proposing a new way to measure and compare corruption across countries - the unbundled corruption index Ang challenges the view that all kinds of corruption are immediately harmful for economic development and that economically successful countries tend to have low rankings on corruption indices such as Transparency International's Corruption Perception Index. By introducing the category of access money that can involve both illegal bribery and institutionalized behaviors such as revolving door practices and lobbying, Ang broadens the understanding of corruption and uncovers a link between access money as a form of corruption and successful economic development. At the same time, her unbundled corruption index allows for understanding patterns of corruption in individual countries and thereby also tailoring solutions to corruption to single country's pathways rather than of-the-rack best practices solutions. Beyond broadening the definition of corruption, it thus allows for theoretically rethinking corruption and delinking patterns of corruption and respective anticorruption measures from the sole focus on best-practice governance experiences in Western countries. Ang therefore provides the basis for rethinking corruption and its link to economic development both in China and also on a comparative scale.

However, at the same time, she offers a controversial view on corruption. The introduction of the unbundled corruption index and the concept of access money mean that she implicitly challenges the assumption that economically developed countries are large free from corruption because they score well in traditional corruption indices. In her view, however, that does not mean that these countries are free from corruption but simply that corruption takes a different form. While this is not per se a weakness of her approach, it certainly has the potential to spark controversy. To apply this concept more broadly, some further conceptual work on access money and its relation with institutionalized behaviors such as lobbyism will be necessary. However, Ang's book 
provides a very rich basis for economists as well as for scholars interested in governance and corruption to embark on this path. Additionally, it also provides food for thought for practitioners engaged in anticorruption activism to think about more appropriate and tailored solutions to individual countries' corruption problems.

Funding Open Access funding enabled and organized by Projekt DEAL.

Open Access This article is licensed under a Creative Commons Attribution 4.0 International License, which permits use, sharing, adaptation, distribution and reproduction in any medium or format, as long as you give appropriate credit to the original author(s) and the source, provide a link to the Creative Commons licence, and indicate if changes were made. The images or other third party material in this article are included in the article's Creative Commons licence, unless indicated otherwise in a credit line to the material. If material is not included in the article's Creative Commons licence and your intended use is not permitted by statutory regulation or exceeds the permitted use, you will need to obtain permission directly from the copyright holder. To view a copy of this licence, visit http://creativecommons.org/licenses/by/4.0/.

Carolin Kautz holds an M.A. in modern Chinese studies and political science from the University of Goettingen. Currently, she is a lecturer and $\mathrm{PhD}$ candidate at the Department of East Asian Studies at the University of Goettingen. Additionally, she is a member of the editing team of ASIEN The German Journal on Contemporary Asia issued by the German Association for Asian Studies. 